\title{
Human security benchmarks: Governing human wellbeing at a distance
}

\author{
ALEXANDRA HOMOLAR*
}

\begin{abstract}
When the United Nations Development Programme formally introduced the concept of human security in 1994, it was widely celebrated as a long-overdue humanist alternative to orthodox models of security. Today, human security is a buzzword for describing the complex challenges that individuals and communities face in achieving safety and wellbeing in an insecure world. This article directs attention away from the emancipatory and empowering qualities commonly ascribed to human security to explore, instead, the specific role of benchmarking within the wider human security agenda. The main focus here is on the ways in which human life has been operationalised, measured, and classified to create indicators that permit judgements about individual security and insecurity. The article argues that although a single global human security benchmark has yet to be established, the main indices used as performance metrics of human insecurity have produced a narrow understanding of what it means to live a 'secure' life and have reinforced the state as the main focal point of international security governance.
\end{abstract}

Dr Alexandra Homolar is Associate Professor of International Security in the Department of Politics and International Studies at the University of Warwick and is Principal Investigator on the 'Enemy Addiction' Research Project, funded by a three-year ESRC Future Research Leaders Fellowship. Prior to joining Warwick, Alexandra held research positions at Yale University, Johns Hopkins University, and the Peace Research Institute Frankfurt. Her work has been published in journals such as the European Journal of International Relations, Journal of Strategic Studies, Review of International Political Economy, and Critical Discourse Studies.

So we rely on statistics in order to build and maintain our own model of the world.

Dudley Seers $(1983)^{1}$

For as long as we are unable to put our arguments into figures, the voice of our science ... will never be heard by practical men.

J. A. Schumpeter (1933), p. $12^{2}$

\section{Introduction}

In 1994, the United Nations Development Programme (UNDP) Human Development Report $^{3}$ (HDR) made a major contribution to reshaping the international security

* This article benefitted from insightful comments by three anonymous reviewers, André Broome and Joel Quirk, and the participants of the Benchmarking in Global Governance (BiGG) Workshop held at the University of Warwick 12-14 March 2014. Any omissions or errors remain the author's own responsibility. The research was supported by the Economic and Social Research Council (grant number ES/K008684/1)

${ }^{1}$ Dudley Sears, The Political Economy of Nationalism (New York: Oxford University Press, 1983), p. 130.

2 Joseph Schumpeter, 'The common sense of econometrics', Econometrica, 1:1 (1933), pp. 5-12 (p. 12).

${ }^{3}$ United Nations Development Programme (UNDP), Human Development Report (HDR) 1994 (New York and Oxford: Oxford University Press, 1994), available at: \{http://hdr.undp.org/sites/default/files/reports/255/ hdr_1994_en_complete_nostats.pdf\} accessed 5 August 2014. 
agenda of the 'New World Order'. The document offered a clear vision of how the people-centric concept of 'human security' should replace the traditional focus on conflict between states, the protection of state borders, and military solutions to security problems. Human security was envisioned as an all-encompassing emancipatory concept that could help to address the many causes of human vulnerability across the globe, including violent conflict, resource deprivation, human rights violations, and environmental change. For many observers and practitioners of global politics, the notion of human security held the promise of a new normative order that could transcend the ideological straitjacket and state-centric orientation of the Cold War international system. ${ }^{4}$

Despite ongoing debates over the meaning, scope, and utility of the concept, ${ }^{5}$ the idea of human security has since been widely celebrated as offering a long-overdue humanist alternative to traditional security governance with the potential to both empower and protect individuals. ${ }^{6}$ Critics, however, have pointed to the orthodox qualities of the concept and sought to raise awareness of the counterproductive practical effects of the human security agenda. ${ }^{7}$ The downsides identified here include the securitisation of everyday life, as well as the norms, power relations, and universalising claims that human security both contains and promotes. ${ }^{8}$ As such scholarship has shown, the emancipatory qualities commonly ascribed to the concept of human security cannot simply be accepted at face value. ${ }^{9}$ It is within this context that this article contributes to the debates on what human security does.

Specifically, the article interrogates the process of translating the abstract notion of human security into concrete measures of a liveable life, which lies at the centre of making judgments about the state of human security. Contemporary political and academic debates have already begun to shine the spotlight on how the concept could and should be operationalised to quantify its multiple dimensions of insecurity

${ }^{4}$ Roland Paris, 'Human security: Paradigm shift or hot air?', International Security, 26:2 (2001), pp. 87-102; Mary Martin and Taylor Owen, 'The second generation of human security: Lessons from the UN and EU experience, International Affairs, 86:1 (2010), pp. 211-24.

5 See, for example, Nicholas Thomas and William T. Tow, 'The utility of human security: Sovereignty and humanitarian intervention', Security Dialogue, 33:2 (2002), pp. 177-92; Alexander J. Bellamy and Matt McDonald, 'The utility of human security: Which humans? What security? A reply to Thomas and Tow', Security Dialogue, 33:3 (2002), pp. 373-77; Edward Newman, 'Critical human security studies', Review of International Studies, 36:1 (2010), pp. 77-94; J. Peter Burgess, 'The ethical challenges of human security in the age of globalization', in Moufida Goucha and John Crowley (eds), Rethinking Human Security (Chichester: Wiley Blackwell and UNCESCO, 2008); Ralph Pettman, 'Human security as global security: Reconceptualizing strategic studies', Cambridge Review of International Affairs, 18:1 (2005), pp. 137-50.; Astri Suhrke, 'Human security and the interests of states', Security Dialogue, 30:4 (1999), pp. 265-76; P. H. Liotta and Taylor Owen, 'Why human security?', Whitehead Journal of Diplomacy and International Relations VII: Winter/Spring (2006), pp. 137-55.

${ }^{6}$ Keith Krause, 'Building the agenda of human security: Policy and practice within the human security network', International Social Science Journal, 59:1 (2008), pp. 65-79 (p. 78).

${ }^{7}$ Nik Hynek and David Chandler, 'Introduction: Emancipation and power in human security', in David Chandler and Nik Marhia (eds), Critical Perspectives on Human Security: Rethinking Emancipation and Power in International Relations (Abingdon: Routledge, 2011), pp. 1-10.

${ }^{8}$ See Ryerson Christie, 'Critical voices and human security: To endure, to engage or to critique?', Security Dialogue, 41:2 (2010), pp. 169-90; Tara McCormack, 'Human security and the separation of security and development', Conflict, Security and Development, 11:2 (2011), pp. 235-60. On human security as 'relation of governance' and as 'principle of formation' see Mark Duffield and Nicholas Waddell, 'Securing humans in a dangerous world', International Politics, 43:1 (2006), pp. 1-23; Kyle Grayson, 'Human security as power/knowledge: the biopolitics of a definitional debate', Cambridge Review of International Affairs, 21:3 (2008), pp. 383-401.

9 See Tara McCormack, 'The limits to emancipation in the human security framework', in Chandler and Hyrek (eds), Critical Perspectives, pp. 99-113; see also David Roberts, 'Human security, biopoverty and the possibility for emancipation', in Chandler and Hyrek (eds), Critical Perspectives, pp. 69-82. 
and threat. ${ }^{10}$ This article both contributes to and goes beyond such considerations as it zooms in on the normative assumptions about the core ingredients for a 'liveable life', upon which any attempt to measure human security is implicitly based. In particular, it explores the process of normalising and essentialising human existence through the lens of global benchmarking practices, which has thus far been sidelined in the discussions over the utility and impact of the human security agenda.

As the editors of this Special Issue highlight, global benchmarks have emerged as a key tool 'for extending public and private authority over distant entities'. ${ }^{11}$ The practice of benchmarking human security converts controversial international development and security policy agendas, complex social phenomena at the domestic level, and normative concepts about human progress into a legible and technocratic terminology that does not reflect their intense contestation. The benchmarking process entails two main steps. In the first step, the concept of human security is disaggregated into distinct categories and indicators that enable the ordinal representation of its complex constituent parts. In the second step, universal standards are constructed and applied to human security indicators to enable the comparative analysis and assessment of human vulnerability across issue areas in numerous countries over time.

The article is structured into two main parts that reflect the process of human security benchmarking. Part one critically discusses this process of operationalising human security with a primary focus on unpacking the indicators used in the 1994 HDR. While the Report is commonly associated with the launch of the human security framework, there has been less appreciation of how it also established and promoted a global agenda for how we map and measure people's living conditions and through what categories. Part two of the article shows that while thinking about human security has generally moved beyond the 1994 HDR, the indicators contained in the Report have continued to inform the practice of benchmarking of human security. Given the current lack of a global 'gold standard' in human security performance metrics and index rankings, the focus here is on a set of seemingly disparate indexes, which tend to be discussed in isolation: the Fragile State Index, Freedom in the World, and the Human Development Index. Although they may not intuitively reflect human security priorities, collectively these indices have provided global governance actors with established datasets, categories, and benchmarks to both judge the state of human security in the world and reinforce the standards constructed to achieve human security. The conclusion underscores the key finding that how human life has been operationalised, measured, and classified in the practice of benchmarking human security is at variance with the emancipatory political rhetoric commonly associated with human security discourses and policies. The main argument of the article is that human security benchmarking has been heavily implicated in the normalisation of controversial policy goals and the promotion of a one-size-fits-all approach to securing humans, which reinforces the state's responsibility for security, rather than challenging or supplanting it. $^{12}$

${ }^{10}$ See Kyle Grayson, 'Human security as power/knowledge', p. 384; Mary Martin and Taylor Owen, 'The second generation'; Kirsti Stuvøy, 'Human security research practices: Conceptualizing security for women's crisis centres in Russia', Security Dialogue, 41:3 (2010), pp. 279-99.

11 André Broome and Joel Quirk, 'Governing the world at a distance: the practice of global benchmarking', Review of International Studies, 41:5 (2015), pp. 819-41.

12 Natasha Marhia, 'Some humans are more human than others: Troubling the "human" in human security from a critical feminist perspective', Security Dialogue, 44:1 (2013), pp. 19-23 (p. 23). 


\section{The politics of indicators and the human security agenda}

Global humanitarian governance is typically couched in universalising terms. It is presented as an 'inherently progressive project' that strives towards 'enacting and creating a world defined by the values of humanity', one that is centred on protecting and improving the lives of the vulnerable. ${ }^{13}$ But any attempt at 'saving strangers ${ }^{14}$ first requires the identification of who is vulnerable and to what; it requires an ability to observe and compare individual experiences of insecurity across multiple social and institutional contexts. Much of contemporary global humanitarian governance relies on a diverse collection of indicators to identify areas of greatest need. These indicators - and the indices and benchmarks that are based on them - serve as proxy measures for the state of the human condition. ${ }^{15}$

Indicators are always constructed and selected based upon a priori conceptions of which observable properties correspond with the phenomenon that is to be captured in a simplified and measurable way. ${ }^{16}$ They never exist in a sociopolitical vacuum, as neutral attributes that stand ready to represent specific social phenomena as data and measurements. Human security is no exception. As the following discussion shows, the process of translating the concept of human security into a series of tangible, measurable objects ('reification') relies on operationalising normative assumptions about what constitutes 'liveable' human existence into observable and measurable categories. The indicators chosen to make judgements about the state of human security thereby function to both concretise and reproduce abstract ideas about what constitutes a 'secure' human life.

\section{Delineating human (in) security in the 1994 Human Development Report}

The release of policy reports by international actors occasionally has significant effects on the evolution of global policy agendas. Prominent examples include the World Bank's 1993 report The East Asian Miracle and the 2006 Stern Review commissioned for the UK government on The Economics of Climate Change. Few publications have had an impact as far-reaching and enduring as the 1994 Human Development Report New Dimensions of Human Security. The document gained its landmark status by officially introducing the notion of human security to the global policy community. While the concept of human security had been articulated earlier at the North-South Roundtable 'Economics of Peace' in Costa Rica in January 1990 and also was included in the 1992 UN Agenda for Peace, ${ }^{17}$ the

${ }^{13}$ Michael N. Barnett, 'Humanitarian governance', Annual Review of Political Science, 16:1 (2013), pp. 379-98 (pp. 381, 383). See also Didier Fassin, 'Humanitarianism: a nongovernmental government', in Michel Feher (ed.), Nongovernmental Politics (New York: Zone Books, 2007), pp. 149-60 (p. 151).

${ }^{14}$ Nicholas J. Wheeler, Saving Strangers: Humanitarian Intervention in International Society (Oxford: Oxford University Press, 2002).

${ }^{15}$ See J. David Singer, 'Variables, indicators, and data: the measurement problem in macropolitical research', Social Science History, 6:2 (1982), pp. 181-217 (p. 186); also UNDP, HDR 1994, p. 3.

${ }^{16}$ Russel Lawrence Barsh, 'Measuring human rights: Problems of methodology and purpose', Human Rights Quarterly, 15:1 (1993), pp. 87-121 (pp. 91, 95-6); Ray Pawson, A Measure for Measures; $A$ Manifesto for Empirical Sociology (London: Routledge, 1989), p. 40. As Singer ('Variables', p. 186) put it, "we think and theorize in terms of concepts, and our data serve as convenient surrogates that represent them and can be subjected to statistical analysis'.

17 'Economics of Peace: A Summary of the North South Roundtable Session in San Jose', Costa Rica, 4-5 January 1990, available at: \{http://ns-rt.org/reports/ECONOMICS\%20OF\%20PEACE.pdf $\}$ accessed 12 September 2014; Boutros Boutros-Ghali, 'An Agenda for Peace: Report of the Secretary-General' (UN Security Council, 1992), available at: \{www.unrol.org/files/A_47_277.pdf $\}$ accessed 25 August 2014 
terminology did not gain traction in the wider public discourse until after the launch of the 1994 HDR. $^{18}$

The pivotal document disaggregated human security into seven interlinked composite parts: economic security, food security, health security, environmental security, personal security, community security, and political security. Intimately connected to the Universal Declaration of Human Rights and radically departing from economic interpretations of the human condition, the 1994 HDR put forward a multidimensional conceptualisation of human security aimed at providing a holistic approach to help pinpoint the greatest areas and sites of individual vulnerability. However, a key prerequisite to mapping the state of human security is the availability of a clear set of guidelines on what precisely the seven categories of human security contain, and what the major signposts are for 'insecurity' in each. Given its aim to address the 'growing challenge' of human security through a new, people-centric paradigm that could shift the focus of security from the state to the 'legitimate concerns of ordinary people' and 'daily lives', we might expect the Report to engage in a 'pro-people' operationalisation of human security. ${ }^{19}$ But this was not the case.

The Report set out to highlight that since the end of the Second World War, humanity had progressed 'on several critical fronts' relevant to human security and affirmed a belief in the possibility to engineer further positive change. ${ }^{20}$ It drew specific attention to the areas of liberty, self-determination, development, healthcare, and economic wellbeing. These were presented as universal values, despite their longstanding liberal heritage. ${ }^{21}$ In order to illustrate the notion of 'human advance', the Report relied on established global comparative measures that conceptually privileged the state rather than individuals and their specific living conditions. For example, the evidence offered in support of human advance included the increase in the number of free countries following the end of the Colonial era, the steady rise in national wealth levels, and a decline in military expenditures after the mid-1980s, as well as an increase in the number of pluralistic and democratic regimes. ${ }^{22}$

This emphasis upon the state as a key reference point for understanding human progress diminished the extent to which it was possible to move beyond a statist bias from the outset. Moreover, the reliance on the state as the primary unit of analysis continued throughout the diagnosis of human vulnerability across the seven categories of human security. A notable example is 'economic security', which featured prominently in the 1994 HDR. While remaining elusive when it comes to a precise definition of economic security, the Report specified that 'an assured basic income' should form the core requirement to be achieved - rather than simply growth in economic output. ${ }^{23}$ Human vulnerability in this area was equated with income insecurity, which was further disaggregated into the notions of insecure working conditions, underemployment, the decreasing value of nominal wages, and the lack of

(para. 16); see also the UNDP, Human Development Report (HDR) 1993 (Oxford and New York: Oxford University Press, 1993), p. iii, available at: \{http://hdr.undp.org/sites/default/files/reports/222/ hdr_1993_en_complete_nostats.pdf $\}$ accessed 12 September 2014.

18 This is based on a Factiva search of major English language print media for the phrase 'human security' from January 1990 to September 2014.

${ }^{19}$ UNDP, HDR 1994, pp. 4, 22.

${ }^{20}$ Ibid., p. 1.

${ }^{21}$ On development as norm, see David Williams, International Development and Global Politics: History, Theory, and Practice (Abington: Routledge, 2012).

${ }^{22}$ UNDP, HDR 1994, pp.1-2.

23 Ibid., p. 24. 
social security as important markers. ${ }^{24}$ Despite extensive discussion of the economic security category, there was little attempt to operationalise a multifaceted understanding of income insecurity into measurable phenomena. 'Data limitations' were cited as the main obstacle to the conversion of the different constituent elements of income insecurity into a set of measurable economic security indicators applicable to all countries. ${ }^{25}$ In order to make quantified inferences about individual economic wellbeing, the Report instead reverted back to the use of readily available national aggregate data as a proxy for economic security. This included a particular emphasis upon Gross National Product (GNP) per capita for developing countries and unemployment rates for industrial countries. ${ }^{26}$

Even if these two measures could accurately represent comparable indicators of aggregate economic conditions across different societies, they are nonetheless highly problematic for making judgements about the economic dimension of human security. This is because they draw upon datasets developed for a different purpose: they assess national economic performance rather than individual economic security. GNP per capita represents the average annual earnings per person as the average total value of all goods and services produced by a country in one year divided by the size of its population. The unemployment rate, meanwhile, shows the percentage of unemployed workers in a country as share of its total labour force. ${ }^{27}$ The two key indicators utilised to provide an assessment of the state of 'economic' human security therefore lack an intuitive relationship to the core requirement of an assured basic income. Moreover, it remains unclear how national economic performance metrics correspond with a people-centric understanding of individual economic security, even for the datasets used. Another fundamental problem, with far-reaching political implications, is the ambiguity of the scale of measurement; that is, the failure to clearly identify the threshold between economic security and economic insecurity. ${ }^{28}$

Each of the components of the human security framework presented in the 1994 HDR suffered from a similar vagueness in relation to conceptualisation and operationalisation. In addition, many of the indicators selected were based on unexplained and value-laden assumptions about what factors are important in making individuals 'secure' across the different core categories of human security which essential ingredients add up to a 'liveable life'. This was particularly problematic in the Report's human development priority of health security. ${ }^{29}$

Health security was defined as the ability of individuals, communities, and societies to avoid premature death. Key sources of health insecurity in developing countries were identified as common infectious and parasitic diseases, such as those linked to poor nutrition and an unsafe environment. For industrialised countries, in

${ }^{24}$ Ibid., pp. $25-6$.

25 Ibid., p. 26.

${ }^{26}$ Ibid. Since 1993, this has become the Gross National Income (GNI). Calculated in national currency, and then converted into US\$, the GNI is the sum of value added by all resident producers plus any product taxes (less subsidies) not included in the valuation of output plus net receipts of primary income (compensation of employees and property income) from abroad'. World Bank, 'GNI per capita, Atlas method (current US\$)', World Bank Open Data (2013), available at: \{http://data.worldbank.org/ indicator/NY.GNP.PCAP.CD $\}$ accessed 5 August 2014.

27 The total labour force is defined as the actual number of people available for work, both unemployed and employed.

28 The Report only notes that $0.1 \%$ of donor countries GNP 'channelled to the poorest nations ... for basic human development priorities' could help bring 'all poor nations up to at least a minimum threshold of human development'. UNDP, HDR 1994, pp. 4-5.

${ }^{29}$ Ibid., pp. 4, 6. 
turn, the main causes noted were cardiovascular diseases and cancer, which were respectively linked to lifestyle choices and environmental contamination. The fundamental problem here is that this is not even a comparison between apples and oranges, but rather between apples and almonds. What is more, as was the case in the category of economic security, the unit of analysis for the main indicator of health insecurity is not specifically concerned with individual wellbeing, but instead focuses upon aggregate outcomes. The degree of health security is defined in terms of premature death at the national level by measuring the annual number of deaths attributed to specific yet different causes in developed and developing countries. With respect to attributes with a negative impact on health security at the individual level, the Report further singled out women and the poor as particularly vulnerable groups within society, specifically depicting maternal mortality rates as an important marker of health security and making an explicit, if unspecified, causal link between poverty and ill-health. ${ }^{30}$

At the heart of the health security section of the Report was the importance of how well societies are able to both counter the sources of insecurity identified and deal with their effects. This reflected an assumption that how a society is organised is causally related to the degree of health security in that society. A higher degree of health security was linked to a liberal understanding of social welfare provision. To measure and compare the relationship between the provision of welfare and health security, the Report listed a range of indicators, which are tied to a set of positions that tend to be associated with a progressive humanitarian agenda. These indicators included the ratio of doctors to people within and across countries, national per capita health spending levels, the percentage of people without health insurance, access to safe water, and malnutrition levels, as well as access to family planning and home care during pregnancy and birth. ${ }^{31}$ This implied an obligation on the state to provide an environment that fosters equal opportunity for individuals to achieve health security by protecting them from disease as much as from unhealthy lifestyles, a concept that is far from being universally accepted. In addition to a paternalistic tendency to shape and govern peoples' life choices in a direction compatible with the way in which health security is defined, the Report failed to bridge the gap between this universalised conception of an entitlement to good health and the particular and differentiated needs associated with health problems between and within societies.

Another major problem with the 1994 HDR is that it relied upon tautological reasoning to provide measurements for specific indicators in one of the core categories of human security by utilising a second. Food security, for example, is one of the leastdefined components of human security in the Report. Eliding the difference between the general availability of food in a country and the ways in which food is spatially distributed within a given territory, food security is understood as the entitlement of people to 'physical and economic access to basic food'. ${ }^{32}$ This implicitly combines two distinct factors: (1) an unequal distribution of food and (2) a lack of purchasing power. The Report used notions of 'undernourishment' and 'born underweight' as observable indicators to quantify individuals' vulnerability in terms of inadequate access to food, without establishing how these indicators should be measured and

\footnotetext{
${ }^{30}$ Ibid., p. 28.

31 Ibid.

32 Ibid., p. 27. The 1994 HDR presents a table on 'Indicators of food security in selected countries', which are based on national aggregate datasets without discussing how they relate to and help to measure 'access to food'.
} 
against what standard. Instead, it established a link between 'access to food' on the one hand, and 'access to assets, employment, and income security' on the other. ${ }^{33}$ The degree of food security is thus at least partially measured by the level of economic security.

This overview of how the human security agenda was delineated in the 1994 Human Development Report illustrates the conceptual flaws and methodological problems inherent in how the various categories of human security were disaggregated and measured. A great deal of ambiguity remains over why these seven core components are essential to human security, what the relationship is between them, and how they overlap in terms of their conceptual scope and relevant indicators. And while the very idea of human security implies that a spectrum of security exists based on standards that would allow for cross-national comparison - a scale that ranges from secure to insecure - no attempt was made in the Report to clarify the high/low values at either end of this spectrum, or the various points that may mark qualitative differences in levels of human security along it.

\section{Human security and international stability}

In the twenty years since its inception, human security has developed into a potent buzzword for describing the complex challenges that individuals and communities face in achieving safety and wellbeing in an insecure world. Many international political actors, in particular from the developed world, have incorporated human security as part of their mandate and policy agenda. This includes states such as Norway, Japan, Canada, and EU member states; international organisations such as the UN and the World Bank; and non-governmental organisations, particularly aid agencies and human rights organisations. ${ }^{34}$

Today, human security is both a standard term in the development policy lexicon and a reference point for a broad understanding of security. It has also has emerged as a constitutive element of global humanitarian governance. An important factor in the continuing popularity of the human security concept and associated terminology is a legacy of how the 1994 HDR secured its meaning, which connected a concern with the security of individual human beings to questions of international peace and stability. This discursive link has two key facets.

First, the capability-centric problematisation of individuals' vulnerability to a wide range of threats beyond those to their immediate physical safety fused negative rights (civil and political) and positive rights (economic and social) within a single meta-concept. Articulated as universally shared concerns irrespective of their particular normative heritage, the core ingredients to a secure, liveable life for all people are today presented as critical objectives of - and challenges to - the broader

33 Ibid.

34 Paris, 'Paradigm shift'; Gary King and Christopher J. L. Murray, 'Rethinking human security', Political Science Quarterly, 116:4 (2001), pp. 585-610 (p. 589); Michael Barnett and Thomas G. Weiss, Humanitarianism Contested: Where Angels Fear to Tread (London: Routledge, 2011), pp. 26-9; cf. OECD, Conflict, Peace and Development Co-Operation on the Threshold of the 21st Century (Paris: OECD, 1997), available at: \{http://pdf.usaid.gov/pdf_docs/Pcaaa817.pdf $\}$ accessed 5 August 2014; International Commission on Intervention and State Sovereignty (ICISS), 'Report: The Responsibility to Protect' (Ottawa: International Development Research Centre, 2001), available at: \{http://responsibility toprotect.org/ICISS\%20Report.pdf\} accessed 5 August 2014); Commission on Human Security, 'Final Report: Human Security Now', available at: \{http://reliefweb.int/sites/reliefweb.int/files/resources/ 91BAEEDBA50C6907C1256D19006A9353-chs-security-may03.pdf $\}$ accessed 5 August 2014. 
international security agenda. They include universal primary education, literacy (in particular for women), access to primary health care and immunisation, freedom from discrimination, and access to food and family planning services, as well as safe drinking water, sanitation, and credit. ${ }^{35}$ The emphasis on human security defined in terms of a 'universalism of life claims' speaks to the empowerment of people across the globe and the promotion of a wide range of positive and negative rights as basic human rights. ${ }^{36}$

The 1994 HDR offered only minimal insights into how the state of human (in)security can be measured, and what the threshold is between security and insecurity. Yet the indicators developed in the Report have helped to secure and reproduce a very specific meaning of 'the vital core' of human life within global humanitarian discourse and the wider international security agenda. ${ }^{37}$ In the context of the metaphorical Global War on Terror, this liberal humanist-inspired construction of what makes a life worthy and 'liveable' beyond mere biological existence has gained rather than lost momentum. ${ }^{38}$

Second, 1994 HDR focused less on capturing how secure or insecure individual human beings are, and more on how well states perform according to the standard of human security. Concentrating attention on states' willingness and capacities to provide equal footing for individuals' life chances as well as to protect both human rights and the general quality of life opened the door for judgements about the condition of human security to be judgements levelled against particular states. The focus on 'good governance' across the different components of human security has both defined the core zones for political action and served to reconfigure the meaning of the state within the fabric of international security. ${ }^{39}$ No longer is the state primarily seen as the principal referent of security, but it is also understood as the core provider and arbitrator of human security.

The shift of the human security agenda away from making inferences about levels of individual human vulnerability also helped to carve out new areas of responsibility for legitimate statehood. This marked a major steppingstone towards the emerging norm of conditional sovereignty, which is the idea that the right of states to be recognised as sovereign actors in the international arena without being subject to external interference is tied to their ability and willingness to protect their own population from harm. ${ }^{40}$ The extent of this responsibility has remained a matter of debate - as has the point at which the international community should act on behalf of those affected. ${ }^{41}$ Nonetheless, the radical departure from treating human insecurity as detached from recognised statehood has risen to prominence

${ }^{35}$ This is summarised in the '20:20 Compact for Human Development'. UNDP, HDR 1994, pp. 7-8; see also Liam Clegg, 'Benchmarking and blame games: Exploring the contestation of the Millennium Development Goals', Review of International Studies, 41:5 (2015), pp. 947-67.

36 Ibid., pp. 13-14; also Des Gasper, 'Securing humanity: Situating "human security" as concept and discourse', Journal of Human Development, 6:2 (2005), pp. 221-45.

37 On the 'vital core' of human life see Sabina Alkire, A Conceptual Framework for Human Security (Oxford: Centre for Research on Inequality, CRISE, 2003).

38 See Marhia, 'Some humans are more human', pp. 21-3, 28; Michael Dillon 'Governing terror: the state of emergency of biopolitical emergence', International Political Sociology, 1:1 (2007), pp. 7-28.

${ }^{39}$ See also James Harrison and Sharifah Sekalala, 'Addressing the compliance gap? UN initiatives to benchmark the human rights performance of states and corporations', Review of International Studies, 41:5 (2015), pp. 925-45. Clegg, 'Benchmarking global development'.

${ }^{40}$ Alexandra Homolar, 'Rebels without a conscience: the evolution of the rogue states narrative in US security policy', European Journal of International Relations, 17:4 (2011), pp. 705-27.

${ }^{41}$ See, for example, Alexander Bellamy, 'The Responsibility to Protect - five years on', Ethics \& International Affairs, 24:2 (2010), pp. 143-69. 
in the post-9/11 era. ${ }^{42}$ In contemporary international security and development discourses, the ability of the state to foster human capabilities and to provide a sociopolitical environment conducive to 'human security' is widely seen as a necessary function of a civilised society and increasingly sets the boundaries of political possibility for interventions by international actors.

The scholarly and policy debates over the utility and scope of the concept of human security continue to evolve. ${ }^{43}$ Nonetheless, the human security indicators set out in the 1994 HDR, however vague, have served to reflect, substantiate, and reproduce the foundational norms of an international order that is centred on a liberal humanist notion of progress and which emphasises self-determination, representative government, and economic wellbeing. They have helped to translate abstract normative conceptions of what a liveable life entails and what the responsibilities of the state should be within this framework into concrete, even actionable, categories. Despite its various shortcomings, 1994 HDR thus played a pivotal role in the normative reconstruction of the post-Cold War international order. By shaping how we categorise and measure human security, the landmark report altered how we interpret and evaluate the success and failure of domestic and international practices. ${ }^{44}$ As we shall see, this continues to reverberate in contemporary global benchmarking.

\section{Benchmarking human (in)security through global indices}

Global indices provide international actors with a powerful political weapon to rate and rank different countries in a systematic and comparative fashion, in order to establish how well they perform against predefined targets and to promote related policy agendas. ${ }^{45}$ Indices are aggregations of a range of different indicators, each derived from a series of observed values that have been placed on a specific scale of measurement to enable a comparative analysis. ${ }^{46}$ They are intended to monitor

42 The universalism entails here 'respecting national sovereignty but only as long as nation-states respect the human rights of their own people'. UNDP, HDR 1994, p. 14. On human security and conditional sovereignty see Miguel De Larrinaga and Marc G. Doucet, 'Sovereign power and the biopolitics of human security', Security Dialogue, 39:5 (2008), pp. 517-37 (pp. 525-8).

${ }^{43}$ See, for example, the debates between the 'broad school', which advances joining together human physical safety, human dignity, and human development, and the 'narrow school', which focuses on individuals' safety from violent conflicts and has received a boost after the ICISS publication, The Responsibility to Protect. See Caroline Thomas, 'Global governance, development and human security: Exploring the links', Third World Quarterly, 22:2 (2001), pp. 159-75; Bellamy and McDonald, 'The utility of human security'; P. H. Liotta and Taylor Owen, 'Sense and symbolism: Europe takes on human security', Parameters, 36:3 (2006), pp. 85-102; Suhrke, 'Human security'; Thomas and Tow, 'Utility of human security'; see also the HDR 1994 Special Issue in Contemporary Politics, 21:1 (2015); Mary Martin and Taylor Owen (eds), Routledge Handbook of Human Security (London: Routledge, 2013).

${ }^{4}$ See also Rebecca Adler-Nissen and Vincent Pouliot, 'Power in practice: Negotiating the international intervention in Libya', European Journal of International Relations, 20:4 (2014), pp. 889-911.

${ }^{45}$ See Ole Jacob Sending and Jon Harald Sande Lie, 'The limits of global authority: How the World Bank benchmarks economies in Ethiopia and Malawi', Review of International Studies, $41: 5$ (2015), pp. 993-1010. Alexander Cooley and Jack Snyder (eds), Ranking the World: Grading States as a Tool of Global Governance (Cambridge: Cambridge University Press, 2015); Beth A. Simmons and Judith G. Kelley, 'Politics by number: Indicators as social pressure in International Relations', American Journal of Political Science (forthcoming 2015); Katja Freistein, 'Effects of indicator use: a comparison of poverty measuring instruments at the World Bank', Journal of Comparative Policy Analysis: Research and Practice (2015, online first); Kevin E. Davis, Benedict Kingsbury, and Sally Engle Merry, 'Indicators as technology of global governance', Law and Society Review, 46:1 (2012), pp. 71-104.

46 Jack Brand, 'The politics of social indicators', The British Journal of Sociology, 26:1 (1975), pp. 78-90 (p. 79). 
complex political, economic, and social phenomena for particular political purposes by expressing a set of disparate indicators on the basis of a common metric to permit assessments about conditions and trends. ${ }^{47}$ As such, they permit the making of judgements and ultimately benchmark the quality of conduct of a unit of analysis, the design of institutions, and sociopolitical outcomes through standardised comparative measures that are linked to specific reference points. ${ }^{48}$

Despite frequent references to human security indicators ${ }^{49}$ and to human security as a benchmark "for an emerging new model of "security", 50 no consensus has emerged on how to operationalise the concept or what the standard is for separating the high-achiever countries in the human security classroom from the underperformers. While mapping the patterns and trends of human insecurity across the globe has played a key role in the wider discourse on humanitarian governance in the international arena, measuring threats to human life and human vulnerability has thus far been characterised by the lack of a specific global human security index. ${ }^{51}$ However, a variety of prominent and well-established global indices, which link to different dimensions of how human security has been delineated since the 1994 HDR, have served as tools and reference points for benchmarking human security. These are typically centred either on states' capacities to provide an environment that is conducive to human security, or how well the degree of development in different countries and regions fosters improvements in human capabilities. The following discussion of the differences between capacity-benchmarking and capabilitybenchmarking illustrates that, although they produce country ratings and rankings for different purposes, these indices have shaped what are today counted as the key performance metrics of human security.

\section{Capacity benchmarking: State stability and freedom scores}

In response to a spike in intra-state conflicts at the beginning of the post-Cold War era, the problem of what have been variously termed 'failed', 'failing', and 'fragile' states took centre stage on the international security agenda. The 1994 HDR is an early example of the classification of 'national breakdown' as one of the main risks to human security and, by extension, a critical threat to international stability. ${ }^{52}$ Although both are highly ambiguous concepts, this link between the level of 'human

${ }^{47}$ On this process of commensuration see Wendy Nelson Espeland and Mitchell L. Stevens, 'Commensuration as a social process', Annual Review of Sociology, 24 (1998), pp. 313-43 (p. 315); On commensuration and global benchmarking practices see André Broome and Joel Quirk, 'Governing the world at a distance'.

${ }^{48}$ See also Theodore M. Porter, Trust in Numbers: The Pursuit of Objectivity in Science and Public Life (Princeton: Princeton University Press, 1995), pp. 28, 45; On standards and benchmarking see Kathleen C. Dominique, Ammar Anees Malik, and Valerie Remoquillo-Jenni, 'International benchmarking: Politics and policy', Science and Public Policy, 40:4 (2013), pp. 504-13.

49 UNESCO-ISS, 'Final Recommendations of the UNESO-ISS Expert Meeting on Peace, Human Security and Conflict Prevention in Africa', Proceedings of the UNESCO-ISS Expert Meeting held in Pretoria, 23-4 July 2001, available at: \{www.issafrica.org/Pubs/Books/Unesco/FinalRcomm.html $\}$ accessed 5 August 2014.

${ }^{50}$ Dan Henk, 'Human security: Relevance and implications', Parameters, 35:2 (2005), pp. 91-106 (p. 92).

51 Miguel De Larrinaga and Marc G. Doucet, 'Sovereign power', p. 528. See the HDI subsection below for attempts to develop such an index. The datasets and indexes the Human Security Report Project focuses relate to a narrow understanding of human security, see, for example, Human Security Audit (2005), available at: \{www.hsrgroup.org/docs/Publications/HSR2005/2005HumanSecurityReport-Part2HumanSecurityAudit.pdf $\}$ accessed 7 May 2015.

52 UNDP, HDR 1994, p. 38. 
security' in a country and the risk of 'state failure' gained further momentum in the aftermath of the terrorist attacks in the US on 11 September $2001 .^{53}$

State failure, broadly defined as the lack of 'stateness', is regarded as a destructive force for human security because it is equated with the absence of the conditions established in the wider human security discourse as essential ingredients to normal statehood and a secure life: reliable rules and physical infrastructure for economic development and social interaction. ${ }^{54}$ Some observers go as far as to argue that to gradually achieve human security in such societies, external 'statebuilding' interventions to create a 'legitimate, professional, and representative state ... is the only way to address the problems of the modern, interconnected world'. ${ }^{5}$ In contemporary debates on whether and how to intervene in a sovereign country's domestic affairs, the link between individual human wellbeing and the nature of social organisation at the state level is made explicit through the idea that legitimate (sovereign) statehood entails both the capacity and responsibility to protect and to provide for the domestic population. Should a state fail to do so, it is argued, the international community has a right and a duty to act. In extreme cases, this duty can include the authorisation of the use of force to ostensibly come to the rescue of the domestic population as external 'liberators' ${ }^{56}$

Despite the politically contested nature of the concept of state failure, the degree to which a state is judged to be 'fragile' or at risk of 'collapse' is generally determined through an evaluation of the 'conditions that threaten the physical integrity, welfare, self-determination, and opportunities' of individual human beings. ${ }^{57}$ Here, the most prominent assessment of state capacity is the Fragile State Index (FSI) (formerly named the Failed State Index) developed by the Fund for Peace and published annually since 2005 . The target audience of the FSI is the international policymaking community, with the explicit aim of providing policymakers with a reliable tool to anticipate and assess problems of 'stateness', and to therefore serve as a 'first step in devising strategies for strengthening weak and failing states'. ${ }^{58}$

The Fund for Peace's global index quantifies the vulnerability of states to collapse or conflict, and ranks and classifies their performance on the basis of

${ }^{53}$ See Charles T. Call, 'The fallacy of the failed state', Third World Quarterly, 29:8 (2008), pp. 1491-507; Homolar, 'Rebels without a conscience', pp. 719-20; UN, 'World Summit Outcome' (2005), paras 138-9, available at: \{www.unrol.org/files $/ 2005 \% 20$ World $\% 20$ Summit $\% 20$ Outcome.pdf $\}$ accessed 5 August 2014; United Nations Security Council (UNSC), 'Resolution 1674' (28 April 2006), available at: \{www.securitycouncilreport.org/atf/cf/\%7B65BFCF9B-6D27-4E9C8CD3CF6E4FF96FF9\%7D/Civilians \%20SRES1674.pdf $\}$ accessed 25 August 2014; UNSC, 'Resolution 1894' (11 November 2009), available at: \{www.securitycouncilreport.org/atf/cf/\%7B65BFCF9B-6D27-4E9C-8CD3-CF6E4FF96FF9\%7D/POC \%20SRES1894.pdf $\}$ accessed 25 August 2014.

${ }^{54}$ Marina Ottoway and Stefan Mair, 'States at risk and failed states: Putting security first', Policy Outlook (Carnegie Endowment of International Peace, September 2004), p. 6, available at: \{www.swp-berlin.org/ fileadmin/contents/products/arbeitspapiere/statesatrisk_ks.pdf $\}$ accessed 5 August 2014.

55 Nate Haken and Patricia Taft, The Dark Side of State Building: South Sudan (Fund for Peace, 2013), available at: $\{\mathrm{http}: / /$ library.fundforpeace.org/fsi13\} accessed 1 August 2014.

${ }^{56}$ G. John Ikenberry and Anne-Marie Slaughter, 'Forging a World of Liberty Under Law, U.S. National Security in the 21 st Century', Princeton Project Papers (Final Report 2006), p. 26; Alexandra HomolarRiechmann, 'The moral purpose of US power: Neoconservatism in the age of Obama', Contemporary Politics, 15:2 (2009), pp. 179-96 (pp. 190-1); also US White House, The National Security Strategy of the United States (Washington, DC, 2002), p. 1; Ban Ki-moon, 'UN Secretary-General Report on "Responsibility to Protect: Timely and Decisive Response"” (2012), available at: \{http://responsibilityto protect.org/index.php/component/content/article/176-the-un-and-rtop/4315-un-secretary-general-releasesreport-on-responsibility-to-protect-timely-and-decisive-response\} accessed 2 June 2014; ICISS, The Responsibility to Protect.

${ }^{57}$ Ottoway and Mair, 'States at risk', p. 2.

58 Ibid. 
these measures. ${ }^{59}$ The FSI bases the rank order of individual states on the total scores of 12 primary indicators across 3 dimensions - social, economic, and political - which are each broken down into an average of 14 further sub-indicators. Each of the primary indicators is an aggregate measure, which rates a particular aspect of state performance on a scale from 0 for the lowest intensity (most stable) to 10 for the highest intensity (least stable). The final aggregate score achieved by a state in the overall composite index is the sum of all 12 primary indicators. State performance is then benchmarked via a scale of possible scores from 0 to 120 . This is in turn divided into four zones of vulnerability: 'sustainable' (0 to 29.9), 'monitoring' (between 30 and 59.9), 'warning' (between 60 and 89.9), and 'alert' (between 90 and 120). The complex and quantitative nature of the FSI aims to signal scientific rigour and to convey an aura of objectivity of the rankings and ratings produced. The focus is nonetheless on judging state viability at the design level of policies and institutions against liberal norms of good governance and legitimate statehood. This includes evaluating the level of democracy, the quality of healthcare provision, the degree of political participation, and the characteristics of electoral processes, as well as the presence of political freedoms and civil liberties. ${ }^{60}$

The adherence to liberal norms of legitimate statehood helps to explain the utility of the Fragile State Index within a wider discourse on humanitarian governance. Moreover, many of the primary and secondary indicators used to construct the index map onto the components of human security outlined in the 1994 Human Development Report and its list of pointers for the risk of national breakdown. ${ }^{61}$ For example, the primary indicator 'poverty and economic decline' is used to assess the level of economic security in a country through the lens of the ability of the state to provide for its population, and includes measurements such as GDP growth, GDP per capita, government deficits, and unemployment rates. ${ }^{62}$ The underlying assumption here is that poverty and economic decline automatically have a negative impact on the ability of the state to provide for its citizens and increases tensions between the wealthy and the poor. The design of the FSI also makes it possible to assess the capacity of states to serve the needs of their populations in the categories of food security and health security. The 'mounting demographic pressures' indicator as a key marker of state vulnerability in the social dimension includes measurements related to diseases, mortality, and water scarcity, as well as malnutrition and food scarcity. Measurements related to water and sanitation, healthcare, and infrastructure, in turn, are an integral part of the 'progressive deterioration of public services' indicator in the political dimension of the FSI. ${ }^{63}$ In its explanation for the recent renaming of the FSI from 'Failed State Index' to 'Fragile State Index', the Fund for Peace has made the link to the human security agenda explicit, suggesting that the goal 'has always been to help improve human security in countries all over the world'. The index, the Fund argues, is created precisely to help set policy priorities and to foster the responsibility of governments in improving livelihoods. $^{64}$

${ }^{59}$ The discussion of the FSI indicators is based on information provided by the Fund for Peace 2014 available at: $\{$ http://ffp.statesindex.org/\} accessed 25 August 2014.

${ }^{60}$ Fund for Peace, 'Indicators', available at: \{http://ffp.statesindex.org/indicators $\}$ accessed 5 August 2014.

${ }^{61}$ UNDP, HDR 1994, pp. 32-40.

${ }^{62}$ Fund for Peace, 'Indicators'.

63 Ibid.

${ }^{64}$ Fund for Peace, 'Name Change', available at: \{http://library.fundforpeace.org/fsi14-namechange\} accessed 25 August 2014. 
The most widely recognised global comparison of whether the institutional designs of states empower or repress their constituents with respect to political rights and civil liberties is much older than the concept of human security itself. Freedom in the World (FIW) is a comparative assessment in the form of a state-centric composite index that has been produced by the US-based think tank Freedom House since 1972. It is derived from data generated through the organisation's Freedom in the World Survey (previously named the Comparative Survey of Freedom). The aim of this annual exercise is to measure and rank the degree of freedom - or democracy for that matter as experienced by individuals in different countries across the globe. In contrast to legal guarantees of liberty enacted by governments, these 'experiences' are understood by the FIW in terms of 'real-world' rights and freedoms, or de facto rather than simply de jure rights. ${ }^{65}$ While many of the FIW components overlap with the FSI indicators, the former centre more explicitly on questions of political rights and civil liberties, which are integral to the political component of human security agenda.

Freedom in the World applies normative standards derived from the Universal Declaration of Human Rights to rank all countries (as well as some disputed and dependent territories). ${ }^{66}$ This is based on their performance across two complex composite indicators, political rights and civil liberties, in order to establish the degree of political freedom and civil liberties that individuals enjoy in each country (or not). These liberties are defined as universal standards that apply 'irrespective of geographical location, ethnic or religious composition, or level of economic development'. They include, for example, measuring the degree of individual rights, freedom of expression, and the rule of law for the civil liberties indicator, as well as political participation, organisational rights, and the functioning of the government for the political rights indicator. In-house and external analysts from a variety of expert community backgrounds undertake the FIW evaluation and assess countries' performance on the basis of a set of pre-defined questions for each of the secondary indicators. The sources on which this assessment is based vary significantly, and include news media reports, academic studies, and publications from civil society watchdogs and other non-governmental organisations as well as from individual professional contacts.

FIW uses a three-tiered assessment system of assigning scores, ratings, and a status for each of the two primary indicators. These in turn consist of a total of twenty-five secondary indicators - ten for the political rights dimension across three subcategories and fifteen for civil liberties dimension across four subcategories - as well as two discretionary political rights questions. A country receives a score for each of the twenty-five secondary indicators by individual analysts awarding points on a scale from 0 (smallest degree of freedom) to 4 (greatest degree). On the basis of the total scores that a country or territory receives in the first step, it is then assigned two ratings - one for political rights and one for civil liberties on a scale from 7 (smallest degree) to 1 (greatest degree). In the final step, the unweighted average is calculated from the political rights and civil liberties ratings, on the basis of which countries are awarded one status on a nominal scale from 1 to 7 that consists of three categories: free (1.0 to 2.5); partly free (3.0 to 5.0); and not free (5.5 to 7.0). This is the overall 'Freedom Rating' produced within the remits of the FIW, and it is widely used by

\footnotetext{
${ }^{65}$ Freedom House, 'Methodology Fact Sheet', available at: \{www.freedomhouse.org/report/methodologyfact-sheet\#.U_3uNkiPL-m \} accessed 25 August 2014. See also \{www.freedomhouse.org/report/freedomworld-2014/methodology\#.VBVmT2Nvxjd accessed 1 September 1014.

${ }^{66}$ This discussion of methodology is based on ibid.
} 
policymakers and researchers to make judgements about the degree of freedom and democracy in countries across the globe.

Despite its longstanding popularity, FIW has a large number of well-known methodological problems. ${ }^{67} \mathrm{~A}$ major issue is the lack in transparency of the coding process, which affects the reliability of the ratings produced and their replicability. It remains unclear, for instance, which kind of answers to the questions on the FIW checklist are translated by the analysts into what measures on the individual scales, and what the underlying theoretical basis is for this relationship between responses and measures. In addition, the source material is not clearly identified, contains subjective observations, and mixes assessments from different issue areas without the specification of their relevance to the FIW ratings. The disaggregated datasets that underlie the ratings produced in the FIW survey are also not easily accessible to researchers outside Freedom House. ${ }^{68}$ Besides a normative bias that privileges systems of social organisation based on modern Western understandings of justice, liberty, freedom, and self-determination, this raises questions about the subjectivity of the scores assigned and the lack of rigour in the data compilation process.

Many aspects of the capacity-benchmarking done by the Fragile State Index and Freedom in the World play an important role in reinforcing the legitimacy of status quo international standards of conduct, institutional design, and policy implementation for states to achieve human security. This includes the principles of good governance, the rule of law, bureaucratic competence, and optimal socioeconomic infrastructure. The FSI and FIW have received sustained scholarly criticism that centres on questioning their methodology, including the principles of replicability and comparability, as well as the operationalisation of the primary and secondary indicators. ${ }^{69}$ While the FIW has begun to address some of these issues and data has become more accessible and transparent, the FSI methodology remains opaque. The status of both indices as 'reputable' global benchmarks across a wide range of policy audiences nonetheless largely persists. The credibility of the country rankings produced by the FSI and FIW with third-party users is primarily rooted in their ability to provide international actors with an information shortcut to judge how well states measure up against the benchmark of stability and freedom, and as such feature prominently in contemporary discourses of human security.

\section{Capability benchmarking: Human development goalposts}

While the rankings produced in capacity benchmarking are frequently linked to key components of the human security agenda, the main global index used to measure

${ }^{67}$ See detailed Gerardo L. Munck and Jay Verkuilen, 'Conceptualizing and measuring democracy: Evaluating alternative indices', University of Illinois at Urbana-Champaign, Comparative Political Studies, 35:1 (2002), pp. 5-34; Diego Giannone, 'Political and ideological aspects in the measurement of democracy: the Freedom House case', Democratization, 17:1 (2010), pp. 68-97.

${ }^{68}$ Recent subcategory scores and aggregates scores have now been made available at: \{www.freedomhouse. org/report/freedom-world-aggregate-and-subcategory-scores\#.VBVmKWNvxjd\} accessed 14 September 2014.

69 See Raymond Duncan Gastil, 'The comparative survey of freedom: Experiences and suggestions', in Alex Inkles (ed.), On Measuring Democracy: Its Consequences and Concomitants (New Brunswick and London: Transaction, 1991); Munck and Verkuilen, 'Conceptualizing and measuring democracy'; Axel Hadenius and Jan Teorell, 'Assessing alternative indices of democracy', Committee on Concepts and Methods Working Paper Series, Political Concepts, 6 (2005), available at: \{www.concepts-methods.org/ Files/WorkingPaper/PC\%206\%20Hadenius\%20Teorell.pdf $\}$ accessed 5 August 2014; Lars Carlsen and Rainer Bruggemann, 'The "Failed State Index" offers Morethan just a simple ranking', Social Indicators Research, 115 (2014), pp. 525-30. 
human security through a focus on individual capabilities (what humans can do and be) laid the groundwork for the development of the concept of human security itself. The Human Development Index (HDI), created by the economists behind the landmark 1994 HDR, Mahbub ul Haq and the Amartya Sen, was presented as a new way of measuring development beyond a focus on state-centric aggregate measures of economic growth and economic means. Introduced in the first Human Development Report in 1990 - and further refined methodologically in the 1991 HDR and conceptually in the landmark 1994 Report $^{70}$ - the HDI has since become the primary comparative quantitative assessment of the state of human development worldwide. Its utility for global humanitarian governance lies in the HDI's aim to enable judgements on a multidimensional understanding of human security through the lens of the width of peoples' choices and the level of their achieved wellbeing. ${ }^{71}$

The Human Development Index seeks to assess progress in human development across three dimensions that are conceptually underpinned by a capability-based approach to poverty, which emphasises the importance of individual agency for development and wellbeing. ${ }^{72}$ These dimensions include: (1) a long and healthy life; (2) access to knowledge; and (3) a decent standard of living. Each of these three dimensions of human development is organised into an index based on a wider set of indicators, such as life expectancy, education enrolment, and GNI per capita. The three areas of health, education, and income were identified in the 1990 Human Development Report as both the 'most critical' measurable development achievements and essential elements of human life - with political freedoms and guaranteed human rights seen as additional rather than core routes towards improving people's choices. ${ }^{73}$

For each dimension, the HDI develops a scale of extreme values by defining a maximum (which was previously the highest observed value in a time series and is now a value capped at a particular point) and a minimum (a subjectively fixed subsistence value, which is seen the basic requirements for a society to survive over time). ${ }^{74}$ Each country is then assigned a value between 0 and 1 in relation to the 'goalposts' marking the high and low end of the human development scale. The value for each sub-index is calculated by abstracting the minimum value from the actually observed value of a measurement. The outcome is then divided by the result of abstracting the minimum value from the maximum value. The HDI value for a country is the geometric mean of the constituent indexes created for the three dimensions centred on different quality-of-life attributes, equally weighted. Following this process of quantification, which methodologically privileges values that are subjectively set over those that are observed, countries are ranked and categorised on

${ }^{70}$ UNDP, Human Development Report (HDR) 1990 (Oxford and London: Oxford University Press 1990), available at: $\{$ http://hdr.undp.org/sites/default/files/reports/219/hdr_1990_en_complete_nostats.pdf $\}$ accessed 5 August 2014); UNDP, HDR 1994, ch. 5.

71 Ibid., p. 10.

72 See Amartya K. Sen, 'Well-being, agency and freedom: the Dewey Lecture 1984', Journal of Philosophy, 82 (1985), p. 203; UNDP, Human Development Report 2010 (New York: Palgrave Macmillan, 2010), p. 16; also Amartya K. Sen, Inequality Reexamined (Cambridge, MA: Harvard University Press, 1992); Sabina Alkire, 'The capability approach as a development paradigm', in Enrica Chiappero-Martinetti (ed.), Debating Global Society: Reach and Limits of the Capability Approach (Milan: Feltrinelli Foundation, 2009).

${ }^{73}$ UNDP, HDR 1990, pp. 10, 12.

74 See UNDP, 'Human Development Reports: Frequently Asked Questions', available at: \{http://hdr.undp. org/en/faq-page $\}$ and $\{\mathrm{http} / /$ hdr.undp.org/en/faq-page/human-development-index-hdi\#t292n52\} accessed 25 August 2014. 
an ordinal scale of human development - very high, high, medium, and low. ${ }^{75}$ Like the FSI and FIW, the HDI has received strong criticism. In addition to problems with its methodological soundness, the quality of its underlying data, and problems with data updating and formula revisions, ${ }^{76}$ this has included questioning the utility of the indicators selected to measure the state of the human condition and the basis for the setting of both indicator goalposts and human development thresholds. ${ }^{77}$

Over the past two decades, several attempts have been made to overcome some of the methodological and conceptual problems raised in connection with the HDI. In terms of relevance to the broad human security agenda, these include notably the Multidimensional Poverty Index, created jointly by the Oxford Poverty and Human Development Initiative and the UNDP in 2010 for the Human Development Reports; ${ }^{78}$ the Generalised Human Development Index, offered by Satya R. Chakravarty; ${ }^{79}$ as well as proposals to develop performance metrics specifically for human security, such as Gary King and Christopher Murray's threshold of generalised poverty, ${ }^{80}$ and David Hastings' prototype Human Security Index (HSI). ${ }^{81}$ However, these alternatives have not overcome the problem of conceptual operationalisation that has plagued the HDI. In all of these cases, indicators have been selected and operationalised on the basis of their apparent conceptual intuitiveness and readily available data, often in the form of complex aggregated datasets.

In the absence of a widely-accepted alternative, the HDI has remained the key global measure used to evaluate the living standards of a country's population in the wider human security discourse through the lens of how well individual states perform and what they have achieved with respect to the select goalposts identified in the individual indicators. The focus in the HDI on the pursuit of development - understood as leading a long and healthy life, acquiring formal educational qualifications, and gaining a decent income - implies a move away from a sensitivity to spatial and cultural differences in conceiving what it is that makes a life valuable, which was a marker of the capabilitiesbased approach to global humanitarian governance from which the HDI emerged. ${ }^{82}$

75 The thresholds set in the 2013 HDR are now relative, with country classifications based on HDI quartiles. See detailed: UNDP, 'Technical Notes' (2013), available at: \{http://hdr.undp.org/sites/default/ files/hdr_2013_en_technotes.pdf $\}$ accessed 5 August 2014.

${ }^{76}$ Hendrik Wolff, Howard Chong, and Maximillian Auffhammer, 'Classification, detection and consequences of data error: Evidence from the human development index', The Economic Journal, 121:553 (2011), pp. 843-70.

${ }^{77}$ For a broad overview, see Milorad Kovacevic, 'Review of HDI Critiques and Potential Improvements', Human Development Research Paper No. 33 (2010), available at: \{http://hdr.undp.org/sites/default/files/ hdrp_2010_33.pdf $\}$ accessed 1 September 2014.

${ }^{78}$ Sabina Alkire and James Foster, 'Counting and multidimensional poverty measurement', Journal of Public Economics, 95:7-8 (2011), pp. 476-87; Sabina Alkire and James Foster, 'Understandings and misunderstandings of multidimensional poverty measurement', Journal of Economic Inequality, 9:2 (2011), pp. 289-314. The 2013 MPI is available at \{www.ophi.org.uk/global-multidimensional-povertyindex-mpi-2013/\} accessed 25 August 2014.

79 Satya R. Chakravarty, 'A generalized human development index', Review of Development Economics, 7:1 (2003), pp. 99-114.

${ }^{80}$ King and Murray, 'Rethinking human security', pp. 590, 606; cf. Taylor Owen, 'Human security conflict, critique and consensus: Colloquium remarks and a proposal for a threshold-based definition', Security Dialogue, 35:3 (2004), pp. 345-87.

${ }^{81}$ David Hastings, 'The human security index: Potential roles for the environmental and Earth observation communities', Earthzine (May 2011) available at: \{www.earthzine.org/2011/05/04/the-human-securityindex-potential-roles-for-the-environmental-and-earth-observation-communities/ $\}$ accessed 25 August 2014; for the HSI see \{www.humansecurityindex.org/\} accessed 25 August 2014.

82 See Martha C. Nussbaum, 'Introduction', in Martha C. Nussbaum and Jonathan Glover (eds), Women, Culture, and Development: A Study of Human Capabilities (Oxford: Oxford University Press, 1993), pp. 1-36 (p. 5); Martha C. Nussbaum, 'Capabilities as fundamental entitlements: Sen and social justice', Feminist Economics, 9:2-3 (2003), pp. 33-59; S. Charusheela, 'Social analysis and the capabilities 
While there were initial disagreements between the HDI architects over the reduction of complex human capabilities to only three main indicators, these were set aside to create a comparative measure of human development with GDP-like traction. ${ }^{83}$

Although the HDI provides measures intimately related to core components of the human security agenda, the UNDP has begun to distance itself from the concept. Since the early 2000s, the framing of policy priorities in the UNDP's Human Development Reports, which contain the HDI and discuss related policy priorities, has devoted less attention to human security components. Instead it has reflected the UN's tendency over the past decade to subsume these within 'threat clusters' to enable the adaptation of the concept and related development goals to the post 9/11 security environment. ${ }^{84}$ With the twentieth anniversary of the concept of human security in 2014, the UNDP acknowledged that the HDI cannot measure human security, and recognised that the concept of human security has lost its some of its initial utility in capturing human vulnerability through the way it has been used in scholarly and political discourses on global humanitarian governance. ${ }^{85}$

While the focus on a holistic and capabilities-oriented approach to improving human lives and achieving human progress has remained at the centre of the UNDP's agenda, it is now dominated by the language of shocks and threats to human development, including economic risks, inequality, health risks, environmental and natural disasters, food insecurity, and physical insecurity. ${ }^{86}$ Although these categories map onto the human security concept introduced two decades ago and reaffirm the focus on states' capacities to 'empower and protect people', ${ }^{87}$ the UNDP has initiated a major rhetorical shift toward the dichotomy of resilience/vulnerability. ${ }^{88}$ This echoes a broader move to recast human security in terms of 'resilience' in (inter) national security discourse. ${ }^{89}$

\section{The multiplier effects of global indices}

Claims about the condition of human security tend to be based on state-centric measures of economic growth, development, good governance, and legitimate statehood. As we have seen, this pattern applies regardless of whether these measures are based on capacity-benchmarking or capability-benchmarking. While human security is sometimes seen as a component of human wellbeing and sometimes

approach: a limit to Martha Nussbaum's universalist ethics', Cambridge Journal of Economics, 33:6 (2009), pp. 1135-52.

${ }^{83}$ See Sakiko Fukuda-Parr, 'The human development paradigm: Operationalizing Sen's ideas on capabilities', Feminist Economics, 9:2-3 (2003), pp. 301-17; Sakiko Fukuda-Parr, 'Rescuing the human development concept from the HDI - reflections on a new agenda', in Sakiko Fukuda-Parr and A. K. Shiva Kumar (eds), Readings in Human Development (Delhi: Oxford University Press, 2004), pp. 117-24.

84 United Nations (UN), 'A More Secure World: Our Shared Responsibility’ (2004), available at: \{www.un. org/en/peacebuilding/pdf/historical/hlp_more_secure_world.pdf $\}$ accessed 5 August 2014; see also UN, 'World Summit Outcome' (2005), available at: \{www.unrol.org/files/2005\%20World\%20Summit $\% 20$ Outcome.pdf $\}$ accessed 5 August 2014.

${ }^{85}$ UNDP, 'Human Development Report' (HDR) (2014), p. 18, available at: \{http://hdr.undp.org/sites/ default/files/hdr14-report-en-1.pdf $\}$ accessed 1 September 2014.

${ }^{86}$ UNDP, 'Frequently Asked Questions'.

${ }^{87}$ UNDP, HDR 2014, p. 5.

${ }^{88}$ UNDP, Towards Human Resilience: Sustaining MDG Progress in an Age of Economic Uncertainty (New York: UNDP, 2011).

${ }^{89}$ David Chandler, 'Resilience and human security: the post-interventionist paradigm', Security Dialogue, 43:3 (2012), pp. 213-29. 
as the meta-concept, ${ }^{90}$ in conjunction the global indices used to assess the degree of human security enable international actors to make quantified connections between vulnerability, underdevelopment, the lack of state capacity, and security. Various practices of benchmarking human security have served to correlate a lack of human development with threats to international peace and stability, in the form of the security-development nexus, the poverty-security nexus, the link between state capacity and security, and the identification of violent conflict as a barrier to development, and fostered the translation of such narratives of causation into policy agendas. ${ }^{91}$ Yet despite the influence of the human security agenda on the evolution of the security discourse over the past two decades, the responsibility for addressing problems of 'insecurity' has remained firmly anchored in the state. ${ }^{92}$

The global indices used in capacity-benchmarking and capability-benchmarking to permit quantifiable inferences and comparative assessments about the state of human vulnerability serve both as key transnational advocacy tools for the monitoring agents that produce them and as data sources for policy activism and political science research. Indeed, the ability to measure can be seen as the symbolic capital of the field of global humanitarian governance. The attractiveness of reducing the complex web of challenges to human security into numbers lies in delivering easyto-digest data chunks that can be acted upon, as well as in the perception of indices as 'efficient, consistent, transparent, scientific, and impartial'. ${ }^{33}$ Through processes of measurement, counting, and calculation, performance metrics of human security that are derived from prominent global indices are perceived to carry a high degree of objectivity, and this can lend authority to actors who may have very little of their own. ${ }^{94}$

Benchmarking human security through global indices does not just conceal the ambiguous nature of the concepts and theories that these rankings are based on. It also multiplies the problems associated with making complex phenomena observable through their conversion into indicators, in particular the oversimplification of the phenomenon being measured and brushing over the norms and values that the indicator itself contains. ${ }^{95}$ In this regard, the goal of international comparability is prioritised above contextual validity and accuracy. As 'composite indices', these global ratings are based on complex datasets that include numerous other indicators often mixing different levels of measurement, as well as applying competing methodologies and data sources - which are aggregated into more encompassing indices. What is measured in global indices, how this is done, and which measures are conceptualised as indicators may appear as objective and apolitical analysis, but remains highly value-laden and subjective. ${ }^{96}$

${ }^{90}$ See King and Murray, 'Rethinking human security', p. 606.

${ }^{91}$ See Owen, 'Human security'. For a critique of these links see Nicholas Waddel, 'Ties that bind: DfID and the emerging security and development agenda', Conflict, Security \& Development, 6:4 (2006), pp. 531-55; Tara McCormack, 'Human security and the separation of security and development', Conflict, Security and Development, 11:2 (2011), pp. 235-60; David Chandler, 'The security-development nexus and the rise of "anti-foreign policy"., Journal of International Relations and Development, 10:4 (2007), pp. 362-86; Maria Stern and Joakim Öjendal, 'Mapping the security-development nexus: Conflict, complexity, cacophony, convergence?', Security Dialogue, 41:1 (2010), pp. 5-30.

92 De Larrinaga and Doucet, 'Sovereign power', p. 531.

93 Porter, Trust in Numbers, p. 21.

${ }^{94}$ Ibid., pp. 8, 23, 74; Michael Ward, Quantifying the World: UN Ideas and Statistics (Bloomington: Indiana University Press, 2004), p. 5.

95 Davis, Kingsbury, and Engle Merry, 'Indicators', particularly pp. 74-7.

96 Ibid.; Ward, Quantifying the World, pp. 11, 25. 
The practice of benchmarking human security reinforces dominant understandings of what responsible states do, what they look like, and the criteria on which they should be judged. In this respect, benchmarking human security indirectly serves as a global standard-setting instrument. It not only permits international political actors to make symbolic judgements about state performance across a wide range of issue areas that are intrinsically value-laden but have all the appearance of being value-neutral, but it also furnishes a persuasive rationale for international intervention to foster acceptance of and, ultimately, adherence to those standards. Benchmarking human security thus facilitates international policy interventions to reduce human vulnerability, which are based on a moral evaluation of states' performance, while masquerading as an objective and value-neutral practice.

\section{Conclusion: Governing humans at a distance}

This article has shown that the concept of human security as a whole and its core dimensions are hard to unpack into clear-cut indicators. The establishment of a threshold that separates 'secure' human beings from those who are 'insecure' in the different categories of human security has remained equally elusive. What human security is has largely been defined by pointing to situations of widely recognised human vulnerability and suffering. We understand the idea of human security only in the abstract, as the binary opposite of an egregious lack of security. This enables external policy interventions in countries' domestic affairs to be justified with reference to the human security agenda and the norms that are integral to it without a clear articulation of what the particular goals of such actions should be, or how they can be achieved through such interventions. ${ }^{97}$

Contemporary political and academic debates on human security have thus far failed to closely examine the concept in light of global benchmarking practices and the normative assumptions about 'human-ness' upon which they rest. Such an examination helps to reveal that the 'human' at the centre of global humanitarian governance is not simply a biological fact. ${ }^{98}$ Indeed, a significant part of the history of the notion of humanity - and humanitarianism as its practical extension - is marked by attempts to conceptualise the essence of desirable human attributes. While both the core of what it means to be 'human' and what the markers are for a liveable life have always remained subject to change over time, the social construction of the civilised 'human' has typically centred around high levels of education, culture, and status across different societies, which has often been linked to processes of inclusion and exclusion. ${ }^{99}$

The human security agenda does not escape this political dynamic of inclusion and exclusion. The global indicators and benchmarks chosen to make judgements about the state of human security reflect and reproduce a series of normative assumptions about what constitutes a 'secure' human life, while excluding alternative attributes that lie outside the limits of this normative framework. Expressed as measurable

${ }^{97}$ Christopher J. Finlay, 'How to do things with the word "terrorist"', Review of International Studies, 35:4 (2009), pp. 751-74.

${ }^{98}$ See Michael N. Barnett, 'Humanitarian governance', Annual Review of Political Science, 16:1 (2013), pp. 379-98 (p. 385); Kyle Grayson, 'The biopolitics of human security', Cambridge Review of International Affairs, 21:3 (2008), pp. 383-401.

99 Detailed in Costas Douzinas, 'The many faces of humanitarianism', Parrhesia, 2 (2007), pp. 1-28 (pp. 1-5); on the polarization of 'humanity', see Ikechi Mgbeoji, 'The civilized self and the barbaric other: Imperial delusions and the challenges of human security', Third World Quarterly, 27:5 (2006), pp. 855-69. 
indicators, the essentialism embedded within the practice of benchmarking human security and the wider human security discourse has not only involved developing a model for what it means to be secure (or not), but also setting standards for a 'good' human life. This has helped to establish the criteria by which what is found to be normal in a statistical sense also becomes normal in a moral sense. ${ }^{100}$ Within this context, the practice of benchmarking human security functions as a symbolic judgement on the quality of countries' conduct, capacities, and institutional design. Because those states that are judged to be underperformers become the focal point of international policy agendas, benchmarking human security functions as an indirect strategy of governance to remake the state at a distance.

Much of the political power of human security indicators and benchmarks rests on their dual role in global governance discourses. On the one hand, they serve to underwrite legitimation claims by international political actors in pursuit of specific policy agendas to change state behaviour. On the other, they act as an 'authorising force' in the creation of international legal standards, such as the emerging norm of the 'responsibility to protect'. ${ }^{101}$ The goal of improving human life is thereby reduced to a narrow range of categories and indicators that are defined at the outset as core dimensions of human security. While the human security label has been invested with political power precisely because its meaning and scope remain contested, the power of benchmarking human security is the capacity to shape, normalise, and naturalise a particular understanding of what makes human life 'secure', while at the same time obscuring the power relations and political normativity that this conception of a secure human life contains. It is the power to identify, in the deceptively neutral language of technocratic assessment, the where, what, and how of international policy interventions in the name of securing humans.

100 Detailed Ian Hacking, The Taming of Chance (Cambridge: Cambridge University Press, 1990).

101 On 'authorizing force', see Habermas's discussion of Hanna Arendt's conception of political power. Jürgen Habermas, Between Facts and Norms: Contributions to a Discourse Theory of Law and Democracy, trans. William Rheg (Cambridge, MA: MIT Press, 1996), p. 148. 